\title{
INFORMATION PLEASE.
}

In an article in the Leacier Post in Au,ust, Mrs. Elizaheth Flock commented on the great influx of Short-eared Owls (Marsh CwIs), and sugjested that this might be due to an abundance of mice brought about by the large amount of unthreshed grain that was left in the open last winter. It will be interestine to note if shorteared Cols stay on longer than usual this fall, or even remain for the winter, as they sometimes do when mice are abundant. Last winter F. Roy, Tullis, recorded one Short-eared. Owl in the Christmas Bird Census.

What is the situation this fall with recard to prairie chicken (Sharp-tailed Grouse)? Last year the majority of our members reported that a merked decline in numbers had taken place.

How well known is our ramesake the Blue Jay? We had imagined that it was a familiar bird, at least in Eastern suskat,chewan, wherever there were trees, so it came as quite a shock to learn that Mrs. Marion Nixon, Wauchope, has never seen one, especially as Blue Jays are reported in Mitchell's Catalozue of askatchewan Birds as nesting in the Moose Mountrins. (By the way, it will be rerembered that we really chose our title because "Sammy Jey" was the "roving reporter" of the Burcess Bedtime stories world).

Have any members ever come across an instance of the coyote, the prairie wolf, praying on decr in winter time? Apparently coyotes will sometimes attack deer when the letter are in a weakened condition at the end of a severe cold spel. .

"In the nature column of an En:lish newspaper received recently, there was an accunt of the Great spotted Woodpecker (close relative of the American Hairy) making a new hole to serve as a winter shelter. Has anyone seen either our own Hairy, or the Downy, excavating a new hole in the fall of the vear? Very little is known, in fact, of where birls pass the lons cold nichts of winter. Chickadees will all pile into one small cavity, but where does "Sammy" Blue Jay spend the hours of darkness? Has anyone ever come across a roost of Bohemian Vaxwings?"

Te repeat this query, which appeared in the second issue of our bulletin, as the question of winter-shelters of birds is an interesting and larcely unsolved problem of bird study.

In answer to our query rejarting the decrease in the number of Cliff Swallows throughout the west, the reneral opinion seems to he that the common house sparrov is largly to blarie, the latter not only destroy the egis and young of the cliff Swallow, but also take possession of the nests.

Last summer Miss Ethel Lloyci came across an actunl instance of this in the Qu'Arpelle Vallev. Under the bridje at the east end of Katepwe Lake she lrcated a nestin colony of Cliff Srallows and, "since the water was only flowin through the center span, it was possible to investijate the two spans on either side." she reports that "ilasterod a jainst the overhead beams were numerous bottle-shaped mud nests of these swallows. Occasionally one caucht a jimpse of the wee face of a young bird at the entrance to the nest. Parents fed the hun fry young and chattered quietly back and forth before darting anay. And then, much to nur surprise, alone came a noisy English sparrow with a grub in his bill. He flew directly to a perfect gourd-like nest, wriggled in throush the crooked neck and disposer. of the srub. It was the first time that members of our party had known that the pesky House Sparrom would evict a cliff swnllow and take possession of the nest." 